\title{
AN EMPIRICAL INVESTIGATION INTO THE LINK BETWEEN INFORMATION TECHNOLOGY IMPLEMENTATION BARRIERS AND COPING STRATEGIES IN THE AUSTRALIAN CONSTRUCTION INDUSTRY
}

\author{
R.A. Stewart ${ }^{1}$, S. Mohamed ${ }^{2}$ and M. Marosszeky ${ }^{3}$
}

\begin{abstract}
The need for the improved implementation of Information Technology (IT) has been identified in both empirical and highly structured research studies as being critical to effective innovation and development at an industry and enterprise level. This need is greater in the construction industry as it has been relatively slow to embrace the full potential of IT based technologies. In an attempt to understand ${ }^{1}$ why the construction industry lags other industries in the uptake and effective implementation of IT, this study reports on an investigation of the Australian construction industry, which identifies the impediments or barriers to IT implementation and the most effective coping strategies to overcome them. A questionnaire-based research approach was adopted for this purpose and a total of 134 valid survey responses were received from various architectural, engineering and construction professionals. The questionnaire was designed to identify perceptions of the most significant barriers to IT implementation and to determine the most 'practical' and 'effective' corresponding coping strategies to mitigate their effects at three decision-making levels: Industry; Organisation and Project.
\end{abstract}

Keywords: information technology, barriers, coping strategies, decisionmaking tiers, construction.

\section{INTRODUCTION}

The uptake of Information Technology (IT) in construction has lagged well behind most other industries. A number of historical, industrial and market forces have shaped the industry's structure and culture, thus affecting the rate, extent and nature of IT adoption in key business processes. Reasons for the slow uptake of IT have been investigated and are well-documented (Marsh and Finch, 1998; Betts 1999; Marosszeky et al., 2000; Stewart et al., 2002). They include the very nature of how the industry constructs one-off projects creating a project rather than a process perspective of production and of investment opportunity, supply chain fragmentation, lack of client leadership, low level of technology awareness and training, necessary up-front investment, on-going maintenance costs and resistance to change. Surveys have also shown that IT is still restricted to administrative and accounting functions, or for highly specific technical functions within the various disciplines (Betts and Clark, 1999; Marosszeky et al., 2000).

Within the building and construction industry cluster in Australia, the constructors make the greatest contribution to employment, 158,000 firms employ on average 2.3 people. Less than one percent of this sector employs more that 20 people. Among designers, the average size of the some 4,600 architectural firms is 4.6 employees and of the approximately 4,600 engineering consultants, 5.6 people (DISR., 1999). As a consequence, a supply chain consisting of hundreds of organisations delivers major projects. With such fragmentation and such small organisations, only a relatively small number of industry leaders are in a position to plan for strategic IT implementation (Marosszeky et al., 2000). Betts (1999) argues that there is a rather limited strategic use of IT in construction and advocates that industry leaders, national agencies and professional

\footnotetext{
${ }^{1}$ Rodney A. Stewart, Lecturer, School of Engineering, Griffith University, PMB 50 Gold Coast Mail Centre, Queensland 9726, Australia, r.stewart@griffith.edu.au

2 Sherif Mohamed, Associate Professor, School of Engineering, Griffith University, PMB 50 Gold Coast Mail Centre, Queensland 9726, Australia, s.mohamed@griffith.edu.au

${ }^{3}$ Marton Marosszeky, Professor, School of Civil and Environmental Engineering, University of New South Wales, Sydney 2052, Australia, M.Marosszeky@unsw.edu.au
} 
institutions should drive towards a more effective strategic exploitation of IT in the sector. Marosszeky et al. (2000) recommend the development of inter-organisational collaboration to re-engineer the supply chain using IT. To assist in the development of a soundly based strategic approach to IT implementation in construction, this paper reports the results of a questionnaire survey-based investigation into the significant barriers to effective IT implementation and coping strategies to overcome them.

The paper first of all presents a literature review of the barriers to effective IT implementation in the construction industry categorised into three (3) discrete levels: industry, organisation and project. Next a similarly structured approach presents coping strategies reported in the literature. The combination of barriers and associated coping strategies provided the background to the development of the survey instrument. The paper then outlines the research methodology, analysis and results. The analysis identifies the most commonly perceived barriers at each level and looks for correlations between barriers and coping strategies.

\section{BARRIERS TO EFFECTIVE IT IMPLEMENTATION}

Effective IT implementation in construction is essential to improve productivity. However, the take-up of innovative IT applications and tools has been limited. In an attempt to understand the reasons for the poor diffusion of IT, some researchers have investigated the barriers to effective IT implementation in construction. Reconciling the relevant literature (Love et al., 1996; Tucker and Mohamed, 1996; NSW; 1998; Marsh and Finch, 1998; DIST, 1998; Baxendale, 1999; Smith, 1999; Marsh and Flanagan, 2000; Love et al., 2001; Marosszeky et al., 2000; Marosszeky, 2002) a holistic view of the top-down effect of these barriers is illustrated in Figure 1.

The barriers detailed in this figure have been drawn from an extensive review of the literature and categorised into the three levels at which IT implementation barriers exist: industry, organisation and project. In the paragraphs that follow, each of these levels and their respective barriers are briefly described.

At all levels, numerous barriers inhibit a higher level of IT diffusion in this industry. At the industry level, the barriers that tend to inhibit the adoption of information and communication technologies are typically related to the competitive nature of the industry, the fragmented supply chain comprising mainly small organisations and the dispersion of expertise. One major contributing barrier is the poor inter-operability between different computer applications and/or organisational management strategies. The cost-driven culture of the industry has a profound effect on the uptake and effective utilisation of IT investments by individual organisations. Small and medium organisations are particularly sensitive to fluctuations in profit margins resulting in limited resources available for IT expenditure.

At the enterprise level, research indicates that many managers are reluctant to invest in innovation and of those that do; they usually provide limited strategic planning to ensure its efficient implementation. Reasoning behind this reluctance to invest in IT may stem from a lack of perceived return on investment on IT expenditure, and a project focus that seeks to achieve the full return on process investment from single projects.

Conservative practices of business managers and limited funding devoted to IT expenditure at the organisation level sets the scene for poor IT implementation on construction projects. However, the overriding factor at 
the project level is their relatively short duration and the very tight time frames under which they are delivered, these factors inhibit training and experimentation with IT at the project level. Moreover, many project staff may have low IT literacy and fear changing their work practices to embrace innovative IT applications and tools.

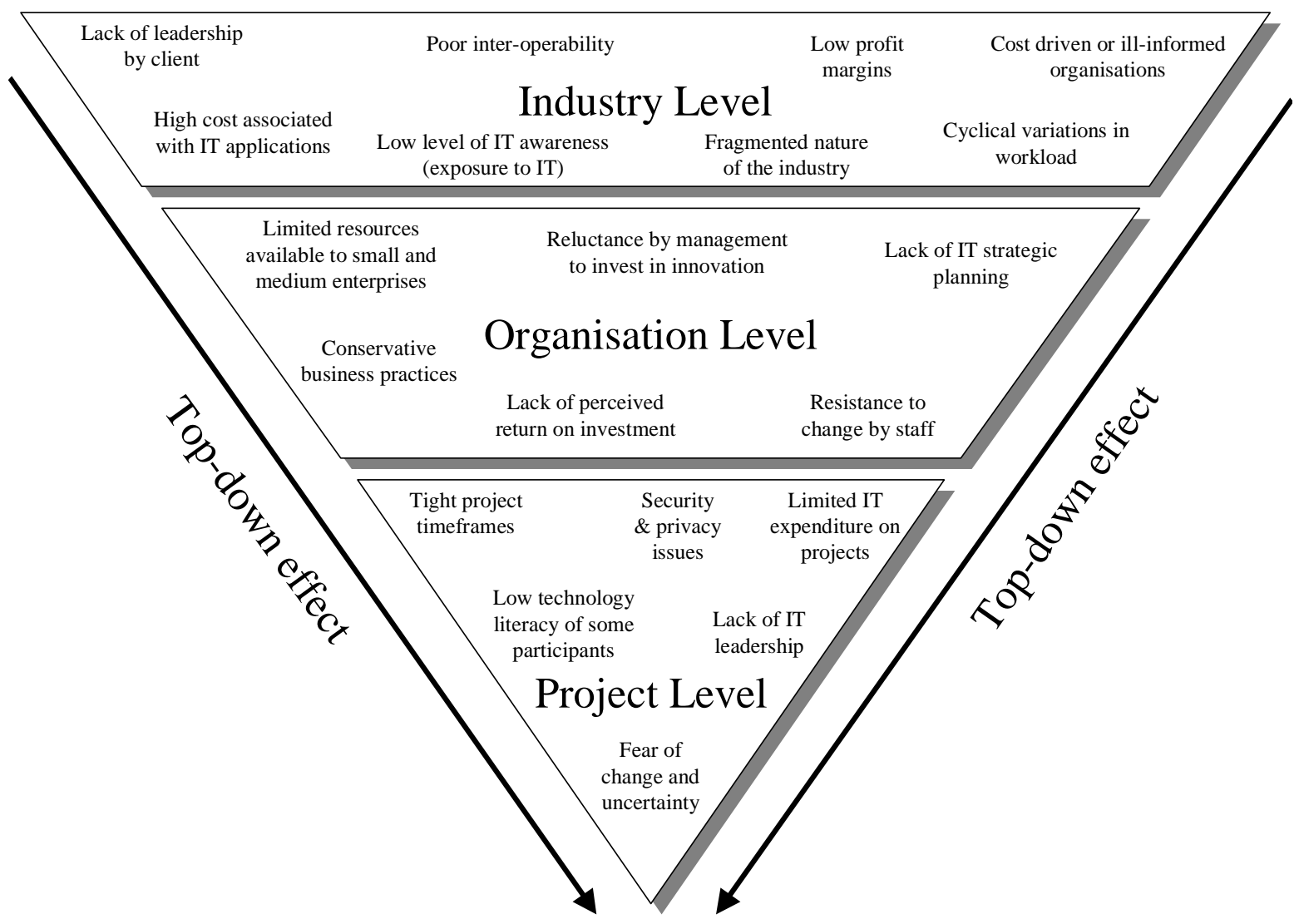

Figure 1: Tiered IT implementation barriers

\section{COPING STRATEGIES}

The importance of coping strategies as a means of identifying and prioritising business needs and technical systems has been recognised in several IT planning approaches (Ward and Griffiths, 1996). However, the use of coping strategies in the context of IT implementation in construction has received limited research focus. The first step in this study was to identify a set of IT coping strategies specifically for the construction industry, this was drawn from the literature (Tucker and Mohamed, 1996; Miozza et al., 1998; Finks, 1998; Pena-Mora et al., 1999; Mitropoulos and Tatum, 2000; Mak, 2001; Duyshart et al., 2002; Marosszeky, 2002; Stewart et al., 2003). Figure 2 provides an overview of the top-down effect of coping strategies on the efficient and effective diffusion of IT in construction. The coping strategies have been categorised in the same three levels as the barriers: industry; organisation, and project. The first of these levels describes industry-specific strategies that are required at the macro level to promote more effective IT implementation. The second level presents strategies to ensure the smooth diffusion of proposed IT projects at the organisation level. The third level describes coping strategies on individual construction projects to ensure that IT has a positive influence on operational processes. All of these coping strategies were included in the questionnaire survey and they were linked to related specific barriers. In the paragraphs that follow, the compiled list of coping strategies, at every level, are briefly described. 


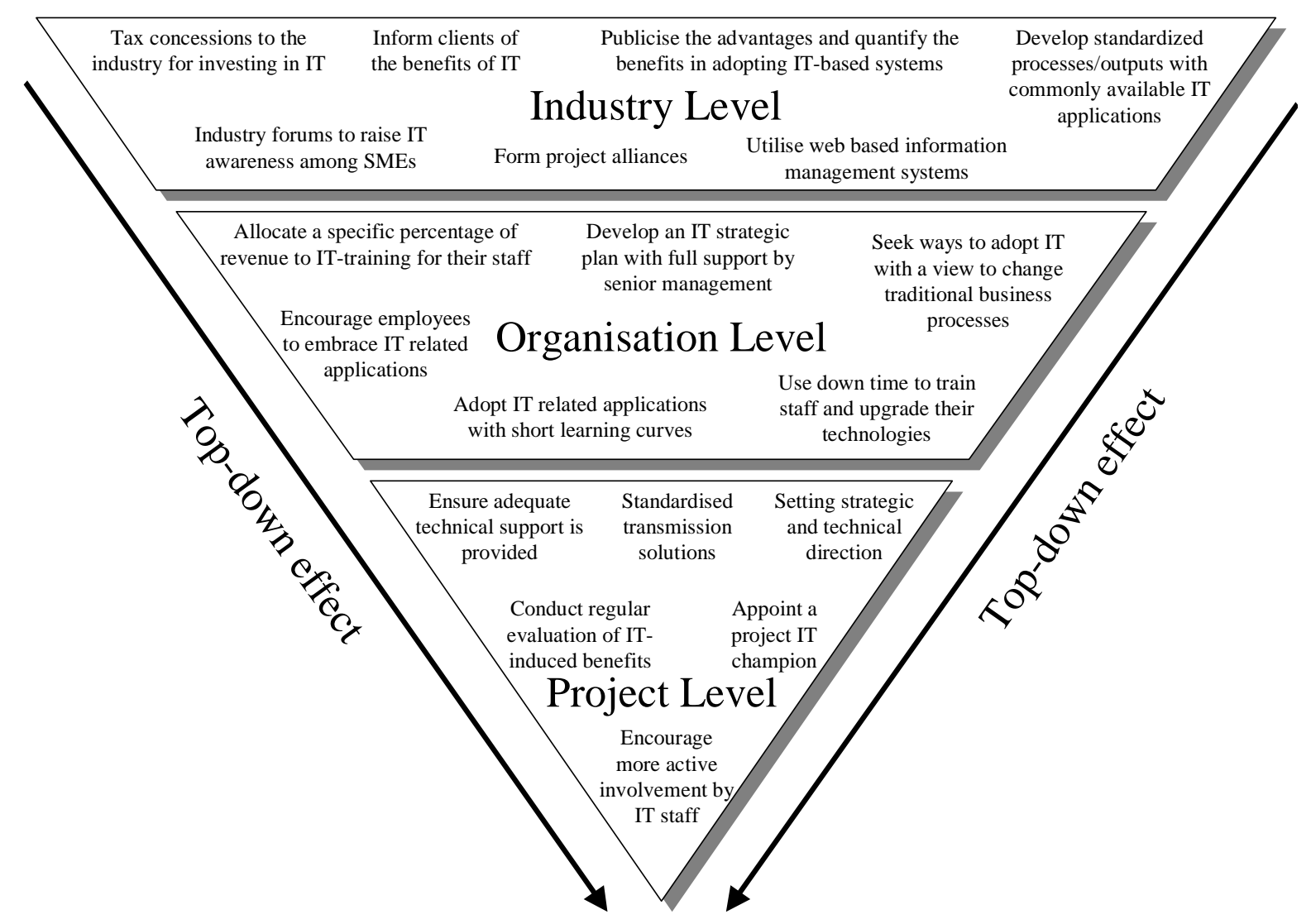

Figure 2: Tiered IT implementation coping strategies

To overcome barriers to IT uptake, practical and effective coping strategies should firstly be implemented at the industry level (Miozzo et al., 1998). This requires a high degree of commitment from Government, institutions and associations to raise awareness of available IT applications/tools and their benefits. Moreover, to overcome the IT literacy gap between the large and small/medium enterprises (SMEs), a series of IT information forums need to be developed. A possible strategy is to procure construction projects using alliance-based management approaches; this ensures that standardised processes/outputs derived from commonly available IT applications are used throughout the supply chain (Stewart et al., 2003). Clients and their project managers need to drive such a process.

At the organisation level a series of forums for promoting standardised IT implementation may aid improved IT diffusion but only with the full support of senior management (Miozzo et al., 1998). Their support will ultimately influence the level of funding allocated towards IT investments, which in turn, dictates the degree of training and support provided (Stewart et al., 2003). Achieving these objectives should encourage employees to embrace IT related applications throughout the organisation and its projects.

Construction projects are very unique environments, which are largely decentralised from the IT architecture of the organisation. These projects face very specific IT implementation challenges and thus require definitive coping strategies to overcome them. Appointing a project IT champion would help ensure an improved appreciation and increased level of utilisation of IT projects by site staff (Pena Mora et al., 1999). Additionally, dedicating IT training and support sessions within the construction program would enhance the degree of IT diffusion (Duyshart et al., 2002). At all 
levels, a series of practical and effective coping strategies are required to help overcome IT implementation barriers.

\section{RESEARCH METHODOLOGY}

The research methodology was developed with the purpose of achieving the following research goals:

- Refinement of the screened list of barriers;

- Ranking the refined barriers in order of significance;

- Linking barriers to coping strategies;

- Establishing the effectiveness and practicality of coping strategies; and

- Recommending guidelines for effective IT implementation.

The study looks at these issues at the above-mentioned three levels.

\section{a. Questionnaire Design}

In order to achieve the above research goals, the questionnaire contained questions on the background of the survey respondents and the IT portfolio of their organisation. This was followed by eight questions relating to the significance of the barriers at the industry level. For these questions, respondents were required to rate the level of significance of each barrier using a five-point Likert scale from 1 to 5 (" 1 " not significant to " 5 " most significant). The next group of questions asked the respondents to link each of the eight barriers to a series of coping strategies and then rate the level of effectiveness (i.e. its potential to overcome one or more of the barriers) and practicality (i.e. ease of implementation) of these strategies. This was done using a scale from 1 to 5 , where " 1 " has very little potential, or most difficult to implement to " 5 " has great potential or very easy to implement, for effectiveness and practicality, respectively. Following this are two sections that incorporate barriers and coping strategies specifically designed for the organisation and project tier, respectively, which also follow the above-mentioned questioning process.

\section{Sampling Procedure}

The questionnaire was targeted at respondents from the Architecture, Engineering and Construction (AEC) industry. Responses were sought from respondents with different position descriptions to gauge perceptions from a broad range of perspectives that are representative of opinions throughout the sector. The questionnaire was sent to 520 professionals from the AEC industry. A small sample of government project managers also participated in the survey. One hundred and forty (140) positive returns were received, representing an average response rate of $27 \%$. This rate appears to be consistent with other reported mail surveys (Fellows and Liu, 1997). Six questionnaires were eliminated due to missing data, leaving a final sample size of 134. Prior to determining significant barriers, analysis of variance (ANOVA) was performed to test whether the group of values of each item were equal for each group of respondents: Principal Engineer/Director/Department Head, Site Engineer/Project Manager, Design Engineer, Architect, HRM/Finance/Administration officer, IT professional and other. This helped clarifying whether or not the opinions of these seven groups were the same for the various barriers at the three levels. The results suggest a consensus between the seven groups in relation to all barriers covered in the survey.

\section{SURVEY RESULTS AND ANALYSIS}

The following sections detail the results of the questionnaire survey starting with a brief classification of the respondent profiles, followed 
by the ranking of barriers according to mean significance, and finally the linking of these barriers to possible coping strategies.

\section{Classification of Respondents}

This section details the profile of the organisation, business, respondent position and IT applications/tools utilised. Firstly, the questionnaire survey was targeted mainly at the private AEC industry (94\%), in addition to, a small percentage (6\%) of government and quasi-government AEC professionals. The questionnaire survey primarily aimed to gauge the perceptions of Australian consultants and construction contracting personnel. However, the respondents' business type profile was categorised into five categories to include secondary businesses types. As expected, most respondents were employed by construction-contracting organisations (48\%), followed closely by consultants (39\%), with government employees (5\%), developer employees (4\%) and other (4\%) making up the remainder of the respondents. The respondents' position description was categorised into seven categories. The position description of Principal Engineer/Director /Department Head was the most common (45\%), followed by site Engineer/Project Manager (16\%), Design Engineer (14\%), Architect (8\%), HRM/Finance/Administration officer (8\%), IT professional (7\%), and other (2\%) .

The next part of the questionnaire asked respondents to detail what IT applications and tools they had available to them on construction projects. As mentioned previously, the survey adopted an information-centric definition of IT, and thus only those types of applications/tools were included in the survey. In total, seven IT applications and tools were included in the survey, as follows: (1) Internet; (2) e-mail; (3) Local Area Network (LAN); (4) Wide Area Network (WAN); (5) Web-Based Project Management Application (WBPMA); (6) Video conferencing; and (7) on-line remote network (mobile). As expected, all respondents had embraced basic IT applications and had access to e-mail and the Internet (100\%). Also, LANs (77\%) were widely adopted by these organisations. However, more innovative project management and communication technologies, such as wide Area Networks (WAN) (37\%), Web Based Project Management Applications (WBPMA) (35\%), video conferencing (23\%) and on-line remote networks (26\%), were not yet widely adopted. It is important to note that this research did not focus on establishing the extent to which innovative IT was utilised, but rather it was more concerned to identify the availability of certain IT based technologies in the work environment and the level to which respondents had an appreciation of the role of IT in managing project information and its associated benefits.

Respondents were also asked to detail the period within which they had implemented specific IT tools. This time frame was used to reflect the link to previous surveys where IT utilisation was limited (Love et al., 1996). A couple of trends can be identified such as: most respondents began to embrace the internet and email in the last 4-6 years; and the more innovative IT applications and tools, that have been implemented, have only been in the last 1-3 years.

\section{Significant Barriers to IT Implementation}

The barriers that had been grouped as a result of the literature review were kept together in the survey and respondents were asked to rate their significance on a scale of one to five as detailed previously. Table 1 details the mean significance scores for the eight industry level barriers labelled $\mathrm{A}$ through to $\mathrm{H}$. Respondents rated barriers $\mathrm{E}$ : Cost driven and/or ill informed client organisations (3.48), H: Poor inter-operability between different applications/organisations (3.46), and G: High cost associated 
with IT applications (3.45) as the most significant barriers. In contrast, respondents did not see barrier D: Lack of leadership by major client organisations (2.96) and B: Cyclical variations in workload activity levels (2.71) as being highly significant barriers to effective IT implementation for communication. Surprisingly, respondents did not link barriers $G$ and $B$ together as one would expect cost and stability of income to be linked. Perhaps this can be explained by the inherent short-term view of practitioners working in the industry.

Table 2 details the mean significance scores for the six organisation level barriers labelled A through to $F$. Respondents rated barriers $E$ : Limited resources available to small and medium enterprises (3.96) and $\mathrm{H}$ : Lack of perceived return on investment of IT expenditure (3.77) as the most significant barriers. Adversely, respondents did not see barriers A: Conservative business practices (3.02) and B: Resistance to change by staff (3.00) as being highly significant barriers to effective IT implementation.

Finally, Table 3 details the mean significance scores for the six project level barriers labelled A through to F. Respondents rated barrier F: Tight project timeframes inhibit training and experimenting with IT (4.00) as the most significant barrier. Adversely, respondents did not see barriers B: Fear of change and uncertainty by some project participants (2.95) as being highly significant barriers to effective IT implementation.

Table 1: Mean significance of industry level barriers

\begin{tabular}{clcc}
\hline Code & Barrier Description & $\begin{array}{c}\text { Mean } \\
\text { Significance }\end{array}$ & Rank \\
\hline E & $\begin{array}{l}\text { Cost-driven and/or ill-informed client } \\
\text { organisations }\end{array}$ & 3.48 & 1 \\
H $\quad \begin{array}{l}\text { Poor inter-operability between different } \\
\text { applications/organisations }\end{array}$ & 3.46 & 2 \\
G & High cost associated with IT applications & 3.45 & 3 \\
C & Low profit margins & 3.33 & 4 \\
F $\quad \begin{array}{l}\text { Relatively low level of IT awareness (exposure } \\
\text { to IT) }\end{array}$ & 3.18 & 5 \\
A & $\begin{array}{l}\text { Fragmented nature of the industry } \\
\text { D } \quad \begin{array}{l}\text { Lack of leadership by major client } \\
\text { organisations }\end{array}\end{array}$ \\
B $\quad \begin{array}{l}\text { Cyclical variations in workload activity } \\
\text { levels }\end{array}$ & 2.07 & 6 \\
\hline
\end{tabular}

Table 2: Mean significance of organisation level barriers

\begin{tabular}{clcc}
\hline Code & Barrier Description & $\begin{array}{c}\text { Mean } \\
\text { Significance }\end{array}$ & Rank \\
\hline E & $\begin{array}{l}\text { Limited resources available to small and } \\
\text { medium enterprises }\end{array}$ & 3.96 & 1 \\
F $\quad \begin{array}{l}\text { Lack of perceived return on investment on IT } \\
\text { expenditure }\end{array}$ & 3.77 & 2 \\
C & $\begin{array}{l}\text { Lack of organisational strategic planning } \\
\text { D }\end{array} \quad \begin{array}{l}\text { Reluctance by management to invest in } \\
\text { innovation at a company level }\end{array}$ & 3.26 & 3 \\
A & $\begin{array}{l}\text { Conservative business practices } \\
\text { B } \quad \text { Resistance to change by staff }\end{array}$ & 3.08 & 4 \\
\hline
\end{tabular}


Table 3: Mean significance of project level barriers

\begin{tabular}{clcc}
\hline Code & Barrier Description & $\begin{array}{c}\text { Mean } \\
\text { Significance }\end{array}$ & Rank \\
\hline F & $\begin{array}{l}\text { Tight project timeframes inhibit training and } \\
\text { experimenting with IT }\end{array}$ & 4.00 & 1 \\
D & Limited IT expenditure on projects & 3.48 & 2 \\
E & Lack of IT leadership on projects & 3.45 & 3 \\
C & Low technology literacy of some project & 3.43 & 4 \\
& $\begin{array}{l}\text { participants } \\
\text { A }\end{array} \quad \begin{array}{l}\text { Security \& privacy issues } \\
\text { B }\end{array}$ & 3.31 & 5 \\
& pearticipants & 2.95 & 6 \\
\hline
\end{tabular}

\section{Linking IT Barriers to Coping Strategies}

The next group of questions asked respondents to link the barriers detailed in Tables 1 through to 3 to a series of coping strategies for the industry, organisation and project levels, respectively, and then rate the effectiveness and practicality of these strategies. The results of this part of the questionnaire survey are detailed in Tables 4 through to 6 for the three levels, respectively, and described as follows. Columns (1) and (2) detail the coping strategies codes and descriptions. Column (3) details the barrier codes and the percentage of the respondents who linked them to relevant coping strategies (i.e. for Table 4: $\mathrm{H}$ (38\%) means that $38 \%$ of respondents linked barrier $H$ to coping strategy CS1). Column (4) details the mean significance of the linked barriers as per Tables 1 to 3 above. Columns (5) and (6) detail the mean effectiveness and practicality scores, respectively, for the linked barriers in question. These scores are combined in Column (7) (i.e. for Table 4: the CS1-H link $=3.36+2.64=$ 6.00 ) to represent a more meaningful rating for the 'usefulness' of the coping strategy for overcoming the linked barriers. Finally, each link is ranked according to the significance of the barrier and the 'usefulness' of the associated coping strategy. For example, for the industry level link CS1-H (38\%) detailed in Column (8) of Table 4, the importance of the link is determined by multiplying the mean significance by the usefulness score $(3.46 \times 6=20.76)$. This ranking provides industry and enterprise leaders with a means to focus on the most important barriers that can be overcome by the suggested coping strategies, see Column (9).

In order to retain the most significant barriers and their respective links to coping strategies, the authors refined the analysis as follows: (1) Remove barriers with a mean significance < 3; (2) Remove links where less than $30 \%$ of respondents linked barriers to coping strategies; and (3) Remove barrier-to-coping strategy links that have a mean usefulness (i.e. mean effectiveness + mean practicality) less than 6. The purpose of these steps is to refine the analysis to ensure that only significant barriers are identified for each level, that coping strategies target their intended barriers, and that the coping strategies are reasonably 'likely' to achieve their desired result. The following sections describe the most significant findings from the study at each level.

\section{Industry level}

In general, respondents indicated that the suggested coping strategies for the industry level barriers are impractical with a mean score for all links as 2.91 (i.e. < 3) while the mean effectiveness for all links was marginally higher at 3.27. The indication that the coping strategies are impractical could be explained by a perception that these IT barriers are out of the control of individual organisations and need to be addressed at 
the industry level. This assertion would reinforce the observation of Miozzo et al. (1998), that Government departments and client organisations should provide guidance to the industry.

In addition to linking the barriers to coping strategies, respondents were asked to suggest other coping strategies for more effective IT implementation. Only two additional coping strategies were suggested: (1) develop tertiary/professional development courses to raise awareness of IT opportunities, and (2) obtain industry agreements on software types and upgrade timing to ensure improved interoperability. It is interesting that only two respondents were willing or able to provide any additional coping strategies. This could reflect pessimism, a sense of limited control or a lack of understanding of the direction that industry should take.

At the industry level, 11 links remain from the above-mentioned refinement process (see Table 4). The CS2-H link (22.32) was ranked first and this was followed closely by the CS4-E link (22.10) as the most appropriate to target by the respondents.

Table 4: Linking barriers to coping strategies - industry level

\begin{tabular}{|c|c|c|c|c|c|c|c|c|}
\hline $\begin{array}{c}\text { Code } \\
\text { (1) }\end{array}$ & $\begin{array}{l}\text { Coping Strategy } \\
\text { Description ( } 2 \text { ) }\end{array}$ & 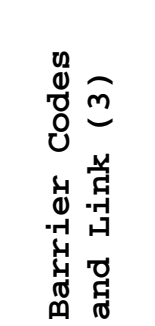 & 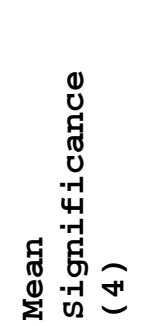 & 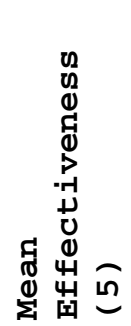 & 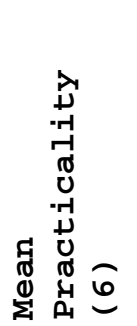 & 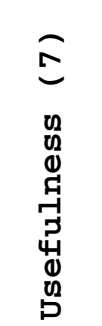 & 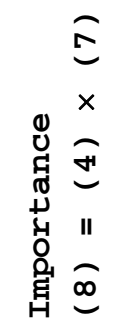 & 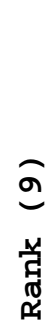 \\
\hline CS1 & $\begin{array}{l}\text { Form project alliances to } \\
\text { bring together key } \\
\text { members to streamline } \\
\text { communications through IT } \\
\text { compatibility }\end{array}$ & H (38\%) & 3.46 & 3.36 & 2.64 & 6.00 & 20.76 & 7 \\
\hline CS2 & $\begin{array}{l}\text { Develop standardized } \\
\text { processes/outputs with } \\
\text { commonly available IT } \\
\text { applications to } \\
\text { facilitate inter- } \\
\text { operability between } \\
\text { members of the value } \\
\text { chain }\end{array}$ & $\mathrm{H}(58 \%)$ & 3.46 & 3.58 & 2.87 & 6.45 & 22.32 & 1 \\
\hline CS3 & $\begin{array}{l}\text { Utilise on-line/web based } \\
\text { information management } \\
\text { systems to facilitate a } \\
\text { common, efficient data } \\
\text { flow system }\end{array}$ & $\begin{array}{l}\text { A }(32 \%) \\
\text { H }(44 \%)\end{array}$ & $\begin{array}{l}3.07 \\
3.46\end{array}$ & $\begin{array}{l}3.38 \\
3.31\end{array}$ & $\begin{array}{l}3.02 \\
2.80\end{array}$ & $\begin{array}{l}6.40 \\
6.11\end{array}$ & $\begin{array}{l}19.65 \\
21.14\end{array}$ & $\begin{array}{c}11 \\
6\end{array}$ \\
\hline CS4 & $\begin{array}{l}\text { Publicise the advantages } \\
\text { and quantify the benefits } \\
\text { in adopting IT-based } \\
\text { communication systems }\end{array}$ & $\begin{array}{l}\text { E } \quad(32 \%) \\
F \quad(47 \%)\end{array}$ & $\begin{array}{l}3.48 \\
3.18\end{array}$ & $\begin{array}{l}2.86 \\
2.98\end{array}$ & $\begin{array}{l}3.49 \\
3.20\end{array}$ & $\begin{array}{l}6.35 \\
6.18\end{array}$ & $\begin{array}{l}22.10 \\
19.65\end{array}$ & $\begin{array}{c}2 \\
10\end{array}$ \\
\hline CS5 & $\begin{array}{l}\text { Inform clients and their } \\
\text { project managers of the } \\
\text { benefits realised through } \\
\text { adopting IT on their } \\
\text { projects }\end{array}$ & $\begin{array}{l}\text { E } \quad(49 \%) \\
F \quad(30 \%)\end{array}$ & $\begin{array}{l}3.48 \\
3.18\end{array}$ & $\begin{array}{l}3.07 \\
3.21\end{array}$ & $\begin{array}{l}3.04 \\
3.12\end{array}$ & $\begin{array}{l}6.11 \\
6.33\end{array}$ & $\begin{array}{l}21.26 \\
20.13\end{array}$ & $\begin{array}{l}4 \\
8\end{array}$ \\
\hline CS6 & $\begin{array}{l}\text { Push for tax concessions } \\
\text { to the industry for } \\
\text { investing in IT }\end{array}$ & $\begin{array}{ll}\text { C } & (37 \%) \\
\text { G } & (56 \%)\end{array}$ & $\begin{array}{l}3.33 \\
3.45\end{array}$ & $\begin{array}{l}3.51 \\
3.55\end{array}$ & $\begin{array}{l}2.84 \\
2.67\end{array}$ & $\begin{array}{l}6.35 \\
6.22\end{array}$ & $\begin{array}{l}21.14 \\
21.46\end{array}$ & $\begin{array}{l}5 \\
3\end{array}$ \\
\hline CS7 & $\begin{array}{l}\text { Conduct industry forums } \\
\text { to raise IT awareness } \\
\text { among small \& medium } \\
\text { enterprises (SMEs) }\end{array}$ & $F(51 \%)$ & 3.18 & 3.20 & 3.00 & 6.20 & 19.72 & 9 \\
\hline
\end{tabular}


The results from the organisation level (Table 5) follow similar patterns to the industry level analysis. As with the industry level results, the respondents indicated that the suggested coping strategies for the organisation level barriers are impractical with a mean score for all links (e.g. average score for all links) of 2.89 (i.e. < 3) while the mean effectiveness for all links was higher at 3.47. Since the only suggestion for a coping strategy at this level was to "educate managers within the organisation" it could be inferred that respondents see many of the suggested strategies as difficult to implement within the operating constraints of the construction industry environment. Perhaps, an IT champion, who has the full backing of corporate management, is required to ensure these strategies can be properly implemented.

At the organisation level, eight links remain from the refinement process (see Table 5). The CS3-E link (27.40) followed by the CS5-E link (24.00) was ranked as the most appropriate to focus on by organisations.

Table 5: Linking barriers to coping strategies - organisation level

\begin{tabular}{|c|c|c|c|c|c|c|c|c|c|}
\hline $\begin{array}{l}\text { Code } \\
(1)\end{array}$ & $\begin{array}{l}\text { Coping Strategy } \\
\text { Description (2) }\end{array}$ & & 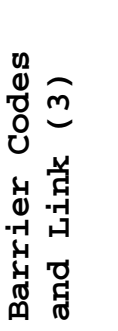 & 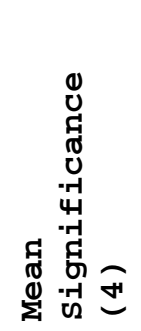 & 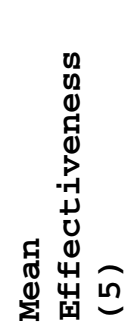 & 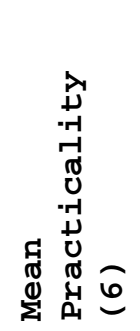 & 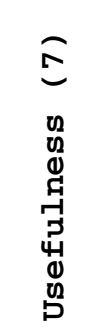 & 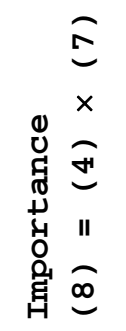 & 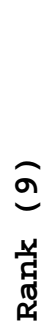 \\
\hline \multirow[t]{2}{*}{ CS1 } & Allocate a specific & B & $(30 \%)$ & 3.00 & 3.43 & 2.89 & 6.32 & 18.96 & 5 \\
\hline & $\begin{array}{l}\text { percentage of revenue } \\
\text { to IT-training for } \\
\text { their staff }\end{array}$ & D & $(31 \%)$ & 3.08 & 3.56 & 2.46 & 6.02 & 18.54 & 7 \\
\hline CS2 & $\begin{array}{l}\text { Encourage employees } \\
\text { to embrace IT related } \\
\text { applications }\end{array}$ & B & $(77 \%)$ & $3 . \odot \odot$ & 3.22 & 3.10 & 6.32 & 18.96 & 6 \\
\hline \multirow[t]{2}{*}{ cs3 } & Adopt IT related & B & $(50 \%)$ & 3.00 & 3.43 & 3.24 & 6.67 & 20.01 & 4 \\
\hline & $\begin{array}{l}\text { applications with } \\
\text { short learning curves }\end{array}$ & $E$ & $(34 \%)$ & 3.96 & 3.54 & 3.38 & 6.92 & $27.4 \odot$ & 1 \\
\hline CS4 & $\begin{array}{l}\text { Seek ways to adopt IT } \\
\text { with a view to change } \\
\text { traditional business } \\
\text { processes }\end{array}$ & A & $(68 \%)$ & 3.02 & 3.37 & 2.65 & 6.02 & 18.18 & 8 \\
\hline CS5 & $\begin{array}{l}\text { Use down time to } \\
\text { train staff and } \\
\text { upgrade their } \\
\text { technologies }\end{array}$ & $\mathrm{E}$ & $(4 \odot \%)$ & 3.96 & 3.39 & 2.67 & 6.06 & 24.00 & 2 \\
\hline CS6 & $\begin{array}{l}\text { Develop an IT } \\
\text { strategic plan with } \\
\text { full support by } \\
\text { senior management }\end{array}$ & C & $(51 \%)$ & 3.26 & 3.67 & 3.05 & 6.72 & 21.91 & 3 \\
\hline
\end{tabular}

Project level

The project level results (Table 6 ) follow a similar pattern, respondents indicating that they considered the suggested coping strategies to be impractical, the mean value for all links is low at (2.88). However, two coping strategies, CS1 and CS2 were perceived to be both practical and effective for overcoming barriers. These relate to providing adequate 
technical support and involving IT staff with construction projects. Other suggestions were again limited with only two responses for the project level: (1) Ensure on-line firewalls/security is adequate; and (2) Develop methods to evaluate the benefits of IT investments. At the project level, only four links remain from the refinement process (see Table 6). The CS1-C link (24.28) was ranked as the most important at the project level.

Table 6: Linking barriers to coping strategies - project level

\begin{tabular}{|c|c|c|c|c|c|c|c|c|}
\hline $\begin{array}{l}\text { Code } \\
(1)\end{array}$ & $\begin{array}{l}\text { Coping Strategy } \\
\text { Description ( } 2 \text { ) }\end{array}$ & 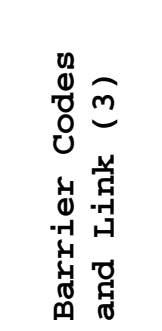 & 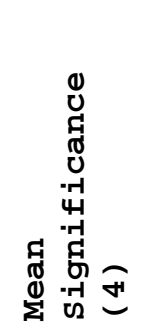 & 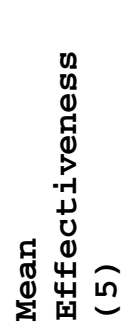 & 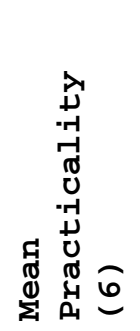 & 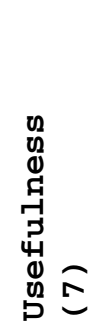 & 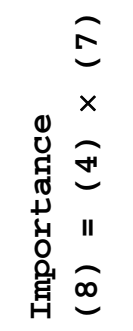 & 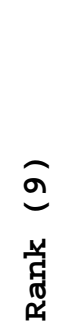 \\
\hline CS1 & $\begin{array}{l}\text { Ensure adequate } \\
\text { technical support is } \\
\text { provided to project } \\
\text { staff }\end{array}$ & C (54\%) & 3.43 & 3.84 & 3.24 & 7.08 & 24.28 & 1 \\
\hline CS2 & $\begin{array}{l}\text { Encourage more active } \\
\text { involvement by IT } \\
\text { staff at the project } \\
\text { level }\end{array}$ & $\begin{array}{l}\text { C }(33 \%) \\
\text { E }(43 \%)\end{array}$ & $\begin{array}{l}3.43 \\
3.45\end{array}$ & $\begin{array}{l}3.50 \\
3.59\end{array}$ & $\begin{array}{l}2.95 \\
3.02\end{array}$ & $\begin{array}{l}6.45 \\
6.61\end{array}$ & $\begin{array}{l}22.12 \\
22.80\end{array}$ & $\begin{array}{l}3 \\
2\end{array}$ \\
\hline $\operatorname{cs3}$ & $\begin{array}{l}\text { Conduct regular } \\
\text { evaluation of IT- } \\
\text { induced benefits at } \\
\text { the project level }\end{array}$ & E $(30 \%)$ & 3.45 & 3.29 & 2.91 & 6.20 & 21.39 & 4 \\
\hline
\end{tabular}

\section{RECOMMENDATIONS}

The following recommendations have been formulated from the above analysis. Tables 7, 8 and 9 detail individual barriers at the three levels together with corresponding coping strategies considered most suitable to overcome them. Utilising the ranking procedure outlined above, the barriers and their corresponding coping strategies have been presented in order of perceived effectiveness. However, organisations may wish to target particular barriers, for instance, to specifically target barrier number five from Table 7 - Relatively low level of IT awareness (exposure to IT). In this case, three coping strategies are recommended and these are listed in order of perceived effectiveness. A company could proceed to develop a detailed plan for the implementation of each coping strategy. The same approach can be followed for the industry and project levels.

To ensure that the empirically determined coping strategies are fully embraced by all tiers of the construction industry it is important that a number of practical recommendations are followed:

- Top management commitment be established and maintained throughout the IT project lifecycle;

- Adequate budgets are allocated towards IT endeavers to ensure that their implementation and long-term utilisation is sustained; and

- Implement IT-induced changes in a planned and progressive manner. 
Table 7: Barriers and coping strategies - industry level

\begin{tabular}{|c|c|c|}
\hline No. & Barrier & Coping Strategies \\
\hline 1 & $\begin{array}{l}\text { Poor inter- } \\
\text { operability between } \\
\text { different } \\
\text { applications/ } \\
\text { organisations }\end{array}$ & $\begin{array}{l}\text { - Develop standardized processes/outputs with } \\
\text { commonly available IT applications to } \\
\text { facilitate inter-operability between } \\
\text { members of the value chain } \\
\text { - Utilise on-line/web based information } \\
\text { management systems to facilitate a common, } \\
\text { efficient data flow system } \\
\text { - Form project alliances to bring together } \\
\text { key members to streamline communications } \\
\text { through IT compatibility }\end{array}$ \\
\hline 2 & $\begin{array}{l}\text { Cost-driven and/or } \\
\text { ill-informed client } \\
\text { organisations }\end{array}$ & $\begin{array}{l}\text { - Publicise the advantages and quantify the } \\
\text { benefits in adopting IT-based communication } \\
\text { systems } \\
\text { - Inform clients and their project managers } \\
\text { of the benefits realised through adopting } \\
\text { IT on their projects }\end{array}$ \\
\hline 3 & $\begin{array}{l}\text { High cost associated } \\
\text { with IT applications }\end{array}$ & $\begin{array}{l}\text { - Push for tax concessions to the industry } \\
\text { for investing in IT }\end{array}$ \\
\hline 4 & Low profit margins & $\begin{array}{l}\text { - Push for tax concessions to the industry } \\
\text { for investing in IT }\end{array}$ \\
\hline 5 & $\begin{array}{l}\text { Relatively low level } \\
\text { of IT awareness } \\
\text { (exposure to IT) }\end{array}$ & $\begin{array}{l}\text { - Inform clients and their project managers } \\
\text { of the benefits realised through adopting } \\
\text { IT on their projects } \\
\text { - Conduct industry forums to raise IT } \\
\text { awareness among small \& medium enterprises } \\
\text { (SMEs) } \\
\text { - Publicise the advantages and quantify the } \\
\text { benefits in adopting IT-based communication } \\
\text { systems }\end{array}$ \\
\hline 6 & $\begin{array}{l}\text { Fragmented nature of } \\
\text { the industry }\end{array}$ & $\begin{array}{l}\text { - Utilise on-line/web based information } \\
\text { management systems to facilitate a common, } \\
\text { efficient data flow system }\end{array}$ \\
\hline
\end{tabular}

Table 8: Barriers and coping strategies - organisation level

\begin{tabular}{|c|c|c|}
\hline No. & Barrier & Coping Strategies \\
\hline 1 & $\begin{array}{l}\text { Limited resources } \\
\text { available to small and } \\
\text { medium enterprises }\end{array}$ & $\begin{array}{l}\text { - Adopt IT related applications with } \\
\text { short learning curves } \\
\text { - Use down time to train staff and } \\
\text { upgrade their technologies }\end{array}$ \\
\hline 2 & $\begin{array}{l}\text { Lack of organisational } \\
\text { strategic planning }\end{array}$ & $\begin{array}{l}\text { - Develop an IT strategic plan with full } \\
\text { support by senior management }\end{array}$ \\
\hline 3 & $\begin{array}{l}\text { Resistance to change by } \\
\text { staff }\end{array}$ & $\begin{array}{l}\text { - Adopt IT related applications with } \\
\text { short learning curves } \\
\text { - Allocate a specific percentage of } \\
\text { revenue to IT-training for their staff } \\
\text { - Encourage employees to embrace IT } \\
\text { related applications }\end{array}$ \\
\hline 4 & $\begin{array}{l}\text { Reluctance by management } \\
\text { to invest in innovation } \\
\text { at a company level }\end{array}$ & $\begin{array}{l}\text { - Allocate a specific percentage of } \\
\text { revenue to IT-training for their staff }\end{array}$ \\
\hline 5 & $\begin{array}{l}\text { Conservative business } \\
\text { practices }\end{array}$ & $\begin{array}{l}\text { - Seek ways to adopt IT with a view to } \\
\text { change traditional business processes }\end{array}$ \\
\hline
\end{tabular}


Table 9: Barriers and coping strategies - project level

\begin{tabular}{cll}
\hline No. & Barrier & Coping Strategies \\
\hline $\mathbf{1}$ & $\begin{array}{l}\text { Low technology literacy } \\
\text { of some project } \\
\text { participants }\end{array}$ & $\begin{array}{l}\text { Ensure adequate technical support is } \\
\text { provided to project staff } \\
\end{array}$ \\
$\mathbf{2} \begin{array}{l}\text { Lack of IT leadership on } \\
\text { projects }\end{array}$ & $\begin{array}{l}\text { Encourage more active involvement by IT } \\
\text { staff at the project level }\end{array}$ \\
& $\begin{array}{l}\text { Encourage more active involvement by IT } \\
\text { staff at the project level } \\
\end{array}$ & $\begin{array}{l}\text { Conduct regular evaluation of IT- } \\
\text { induced benefits at the project level }\end{array}$ \\
\hline
\end{tabular}

\section{CONCLUDING REMARKS}

The use of IT is growing rapidly, and is expected to become the dominant technology for business communication between organisations in the near future. However, data from the National office for the Information Economy (NOIE, 2000) shows that the national construction industry lags well behind other industries in its uptake of IT based technologies.

This paper has presented an extensive literature review, which was used to identify barriers to, and coping strategies for, IT implementation. Based on the literature review, IT implementation barriers and coping strategies were identified and categorised into three levels; namely industry, organisation and project level. The first of these groups focuses on macro level industry-specific factors and barriers. The second group deals with factors and barriers at the organisational level which impact on the efficient and effective diffusion of IT projects throughout an enterprise. The third and final group presents barriers and coping strategies on individual construction projects which impact on the positive influence of IT on operational processes.

The questionnaire survey validated the identified set of barriers to IT implementation and the corresponding coping strategies that can assist to overcome them. From the refinement process the most significant barriers to IT implementation and the most 'practical' and 'effective' coping strategies to overcome them were selected.

The most significant barrier for each level and the most 'useful' coping strategies to overcome them, respectively, were identified as:

o Industry level: Poor interoperability between different applications/organisations; Develop standardized processes/outputs with commonly available IT applications to facilitate inter-operability between members of the value chain;

o Organisation level: Limited resources available to small and medium enterprises; Adopt IT related applications with short learning curves;

o Project level: Low technology literacy of some project participants; Ensure adequate technical support is provided to project staff.

From the above it could be concluded that the issue of interoperability between different electronic exchanges is a major challenge facing the industry. This may well explain the continual growth in using web-based applications - as an alternative - to facilitate increased efficiency in data exchange. It may also pave the way for future development of open standards, which is a vital component in attracting small and medium enterprises to participate broadly in adopting information and communication technologies. Such enterprises would definitely opt for technologies with short learning curves to avoid stretching their limited 
resources and to provide opportunities for the skilling of their staff. This agrees well with the high degree of consensus in the respondents' perception that IT training and technical support is one of the most 'practical' and 'effective' means to improve IT implementation.

In conclusion, this paper has identified critical barriers to IT implementation and a series of useful coping strategies as perceived by Australian construction professional at the industry, enterprise and project levels.

\section{ACKNOWLEDGEMENTS}

The authors would like to thank the Australian Centre for Construction Innovation (ACCI) for providing the necessary funding to undertake this project. Also, the authors appreciate the input provided by the industry practitioners who participated in the questionnaire survey.

\section{REFERENCES}

Baxendale, A.T., 1999, IT on the construction site - contrasting cases, Proceedings of the CIB W55 and W65 Joint Triennial Symposium, Customer Satisfaction: A Focus For Research and Practice, Cape Town, South Africa, September 5-10.

Betts, M., 1999, Strategic Management of IT in Construction, Blackwell Science, oxford.

Betts, M., Clark, P., 1999, The scope for IT in construction, In Betts, M., editor, Strategic Management of IT in Construction, Blackwell Science, oxford, chapter 5.

Department of Industry, Science and Tourism, 1998, Building for Growth: A Draft Strategy for the Building and Sonstruction Industry, Department of Industry, Science and Tourism, Canberra, Commonwealth of Australia.

Department of Industry, Tourism and Resources, 1999, Information Technology in the Building \& Construction Industry: Current Status \& Future Directions, http://Www.isr.gov.au/industry/building/analysis.pdf.

Duyshart, B., Mohamed, S., Hampson, K.D. Walker, D.H.T., 2003, Enabling improved business relationships- how information technology makes a difference, In Walker, D.H. and Hampson, K.D., editors, Procurement strategies, Blackwell Science, 0xford, 123-166.

Fellows, R., Liu, A., 1997, Research Methods for Construction, Blackwell Science, Australia.

Fink, D., 1998, Guidelines for the successful adoption of information technology in small and medium enterprises, International Journal of Information Management, 18, 243-253.

NSW Department of Public Works and Services, 1998, Information Technology in Construction - Making IT Happen, Sydney.

Love, P., Irani, Z., Li, H., Cheng, E., Tse, R., 2001, An empirical analysis of the barriers to implementing e-commerce in small-medium sized construction contractors in Victoria, Australia, Construction Innovation, 1, 31-41.

Love, P.E.D., MacSporran, C., Tucker, S.N., 1996, The application of information technology by Australian contractors: towards process re- 
engineering, Proceedings of the International Group on Lean Construction (IGLC) 96, Fourth Annual Conference, Birmingham, August 26-27.

Mak, S., 2001, A model of information management for construction using information technology, Automation in Construction, 10, 257-263.

Marosszeky, M., Sauer, C., Johnson, K., Karim, K., Yetton, P., 2000, Information technology in the building and construction industry: the Australian experience, INCITE 2000-Implementing IT to obtain a competitive Advantage in the $21^{\text {st }}$ Century, The Hong Kong Polytechnique University, Hong Kong, 183-196.

Marosszeky, M., 2002, An overview of e-business impacts on product supply in construction, The European Conference on Information and Communication Technology Advances and Innovation in the Knowledge Society, Salford, 18-21 November.

Marsh, L., Finch, E., 1998, Attitudes towards auto-ID within the UK construction industry, Journal of Construction Management and Economics, 16, 383-388.

Marsh, L., Flanagan, R., 2000, Measuring the costs and benefits of information technology in construction, Engineering, Construction and Architectural Management, 7, 423-435.

Miozzo, M., Betts, M., Clark, A., Grilo, A., 1998, Deriving an IT-enabled process strategy for construction, Computers in Industry, 35, 59-75.

Mitropoulos, P., Tatum, C.B., 2000, Forces driving adoption of new information technologies, Journal of Construction Engineering and Management, 126, 340-348.

National Office of the Information Economy, 2001, The Current state of Play: June 2001, Commonwealth of Australia, Canberra, 74p.

Pena-Mora, F., Vadhavkar, S., Perkins, E., Weber, T., 1999, Information technology planning framework for large-scale projects, Journal of computing in Civil Engineering, october, 226-237.

Smith, A., 1999, Computing in construction procurement: some experience from Hong Kong, Australian Institute of Building Papers, 9, 143-155.

Stewart, R.A., Miller, C., Mohamed, S., Packham, G., 2003, Sustainable development of construction small and medium enterprises (SMEs): IT impediments focus, In Amor, R. editor, Proceedings of the W78 International Conference on Information Technology in Construction - Construction IT Bridging the Distance, 23-25 April, Auckland, New Zealand, 361-368.

Stewart, R.A., Mohamed, S., Daet, R., 2002, Strategic implementation of IT projects in construction: A case study, Journal of Construction Automation, 11, 681-694.

Tucker, S.N., Mohamed, S., 1996, Introducing information technology in construction: pains and gains, Proceedings of the CIB-W65 Symposium on Organisation and Management of Construction, Glasgow, 348-356.

Ward, J., Griffiths, P., 1996, Strategic Planning for Information Systems, $2^{\text {nd }}$ edition, Wiley, Chichester. 